\title{
Himalayan Giant Honey Bee, Cliff Honey Bee (suggested common names) Apis laboriosa Smith (Insecta: Hymenoptera: Apidae) ${ }^{1}$
}

\author{
Michelle Gregory and Cameron Jack ${ }^{2}$
}

The Featured Creatures collection provides in-depth profiles of insects, nematodes, arachnids and other organisms relevant to Florida. These profiles are intended for the use of interested laypersons with some knowledge of biology as well as academic audiences.

\section{Introduction}

Although the Himalayan giant honey bee Apis laboriosa Smith (Figure 1), is the largest honey bee species in the world, it is also one of the least studied. It has a distribution mostly concentrated in the Hindu Kush Himalayan region of southern Asia. This species is a member of the subgenus Megapis, along with Apis dorsata. Apis laboriosa was long considered to be a subspecies of Apis dorsata (Koeniger et al. 2011) until 1980 when Sakagami described Apis laboriosa as a separate species (Engel 1999; Sakagami et al. 1980), which was later supported by genetic sequencing (Cao et al. 2012). Apis laboriosa builds a large open nest with a single comb, usually on rocky cliffsides. Here, we highlight the unique characteristics of Apis laboriosa and compare it to other honey bee species, particularly the other giant honey bee, Apis dorsata.

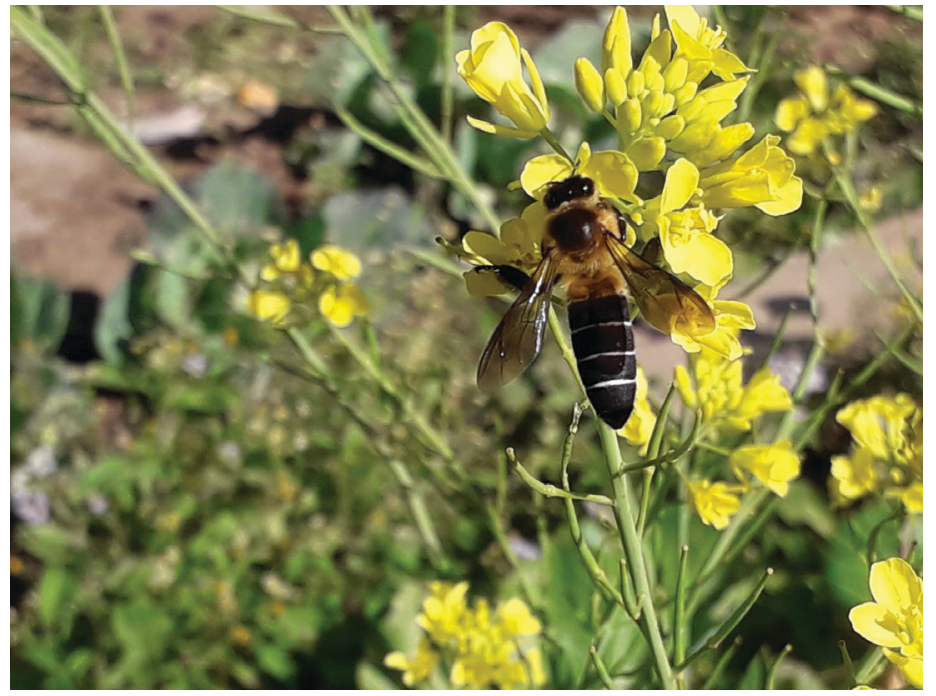

Figure 1. An Apis laboriosa worker (non-reproductive female) in Trongsa Dzongkhag, Trongsa District, Bhutan with an elevation of approximately $6,759 \mathrm{ft}(2,060 \mathrm{~m})$ above sea level. Credits: pemthrinlai https://www.inaturalist.org/ observations/18594655, (CC BY-NC-ND 4.0) https://creativecommons. org/licenses/by-nc-nd/4.0/

\section{Distribution}

While Apis dorsata is widely distributed from the Indian subcontinent to Southeast Asia, the distribution of Apis laboriosa is primarily found in the Hindu Kush Himalayan (HKH) region of southern Asia (Figure 2). It has a westernmost border of western Nepal and a southeast border that expands through the northern borders of Laos

1. This publication is EENY-777, one of a series of the Entomology and Nematology Department, UF/IFAS Extension. Original publication date August 2021. Visit the EDIS website at https://edis.ifas.ufl.edu/ for the currently supported version of this publication. This document is also available on the Featured Creatures website at http://entomology.ifas.ufl.edu/creatures.

2. Michelle Gregory, graduate student (M.S. 2020), and Cameron Jack, apiculture lecturer and distance education coordinator, UF/IFAS Entomology and Nematology Department, Gainesville FL 32611.

The Institute of Food and Agricultural Sciences (IFAS) is an Equal Opportunity Institution authorized to provide research, educational information and other services only to individuals and institutions that function with non-discrimination with respect to race, creed, color, religion, age, disability, sex, sexual orientation, marital status, national origin, political opinions or affiliations. For more information on obtaining other UF/IFAS Extension publications, contact your county's UF/IFAS Extension office. U.S. Department of Agriculture, UF/IFAS Extension Service, University of Florida, IFAS, Florida A \& M University Cooperative Extension Program, and Boards of County Commissioners Cooperating. Andra Johnson, dean for UF/IFAS Extension. 
and Vietnam. It can be found as far north as the northern border of India into southern China (Otis 1996; Roubik et al. 1985).

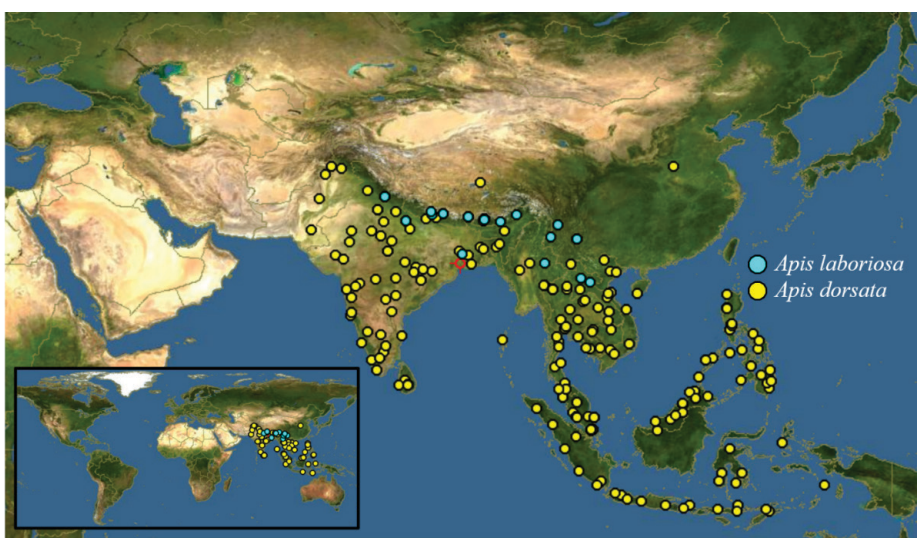

Figure 2. Global distribution of Apis laboriosa in southern Asia which shows some overlap with the related species Apis dorsata.

Credits: Map designed by The Polistes Corporation created by Discover Life https://www.discoverlife.org/mp/20m? $\mathrm{r}=.125 \& \mathrm{la}=22.5 \& \mathrm{lo}=87 \& \mathrm{kin}$ $\mathrm{d}=$ Apis+dorsata,Apis+laboriosa \&map $=S A T W \& w=1200$

\section{Description}

Apis laboriosa is the largest extant honey bee species in the world with a body length slightly larger than Apis dorsata (Figure 3). Apis laboriosa workers average just over 1.2 in (3 $\mathrm{cm}$ ) in length. The scutellum (dorsal side of thorax) is dark brown to black with long yellowish hairs. All segments of the abdomen are dark (Kitnya et al, 2020) (Figure 4).
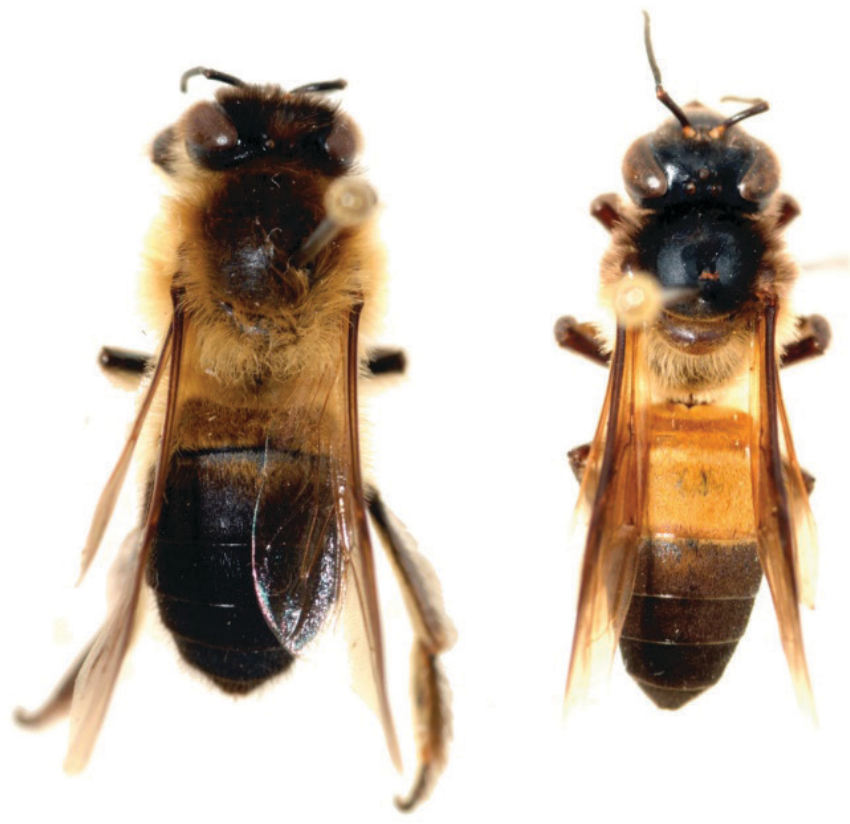

Figure 3. Apis laboriosa (left) and Apis dorsata (right) workers for comparison. Scale bar: 0.4 in $(1 \mathrm{~cm})$.

Credits: From "Geographical distribution of the giant honey bee Apis laboriosa Smith (Hymenoptera, Apidae)" by Kitnya et al, 2020

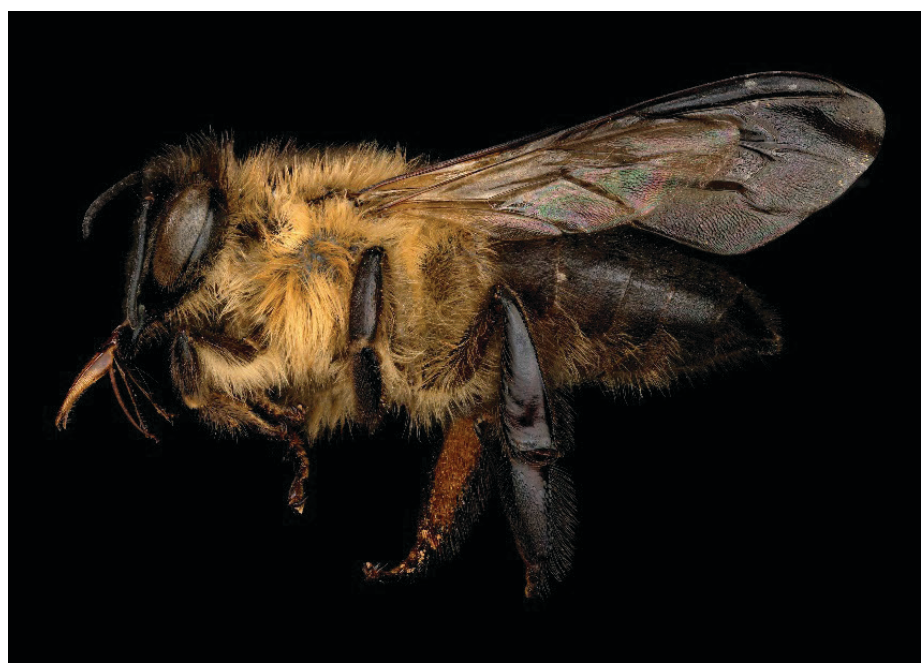

Figure 4. Apis laboriosa, worker (non-reproductive female) lateral view. Credits: Chelsey Ritner chelsey.ritner@usda.gov, Exotic Bee ID, USDA APHIS PPQ, Bugwood.org, (CC BY-NC 3.0) https://creativecommons. org/licenses/by-nc/3.0/

\section{Life Cycle}

Like all other honey bee species, Apis laboriosa are holometabolous insects that undergo a complete metamorphosis with the following stages: egg, larva, pupa, and adult. Details regarding Apis laboriosa development are largely unknown, most likely because the nests are difficult to access for study. However, inferences can be made based on the development of Apis dorsata (Tan 2007).

\section{Egg}

The life of a honey bee starts when an egg laid by the queen in a wax cell. The larva will eclose (emerge) from the egg after three days.

\section{Larva}

As the larva ecloses from its egg, it is now dependent on the workers (its sisters) for food and care. A healthy larva takes on a plump $\mathrm{C}$ shape on its side in the cell that has liquid food in the bottom of the cell. As the larva matures, it will send a chemical cue to the workers that the cell is ready to be capped with wax after nearly six days.

\section{Pupa}

This is a non-feeding growth phase where the pupa will remain undisturbed for 11 days. Each day the pupa loses larval characteristic and gains more adult features.

\section{Adult}

When the pupa is a fully formed adult, it emerges from the capped cell, crawls out, and joins its sisters in colony work. 
In smaller honey bee species like Apis mellifera, the workers make longer cells for drone brood on the periphery of the nest. Apis laboriosa and Apis dorsata workers are very large, therefore the sizes of workers and drones are indistinguishable in the nest (Koeniger et al. 2011). Currently, almost no information is available regarding Apis laboriosa queens. In Figure 5, an adult worker crawls over a comb with various stages of larvae and pupae visible. For reference, the cells are approximately 0.25 in $(0.6 \mathrm{~cm})$ across and 0.8 in $(2.0$ $\mathrm{cm}$ ) long (Valli and Summers 1988).

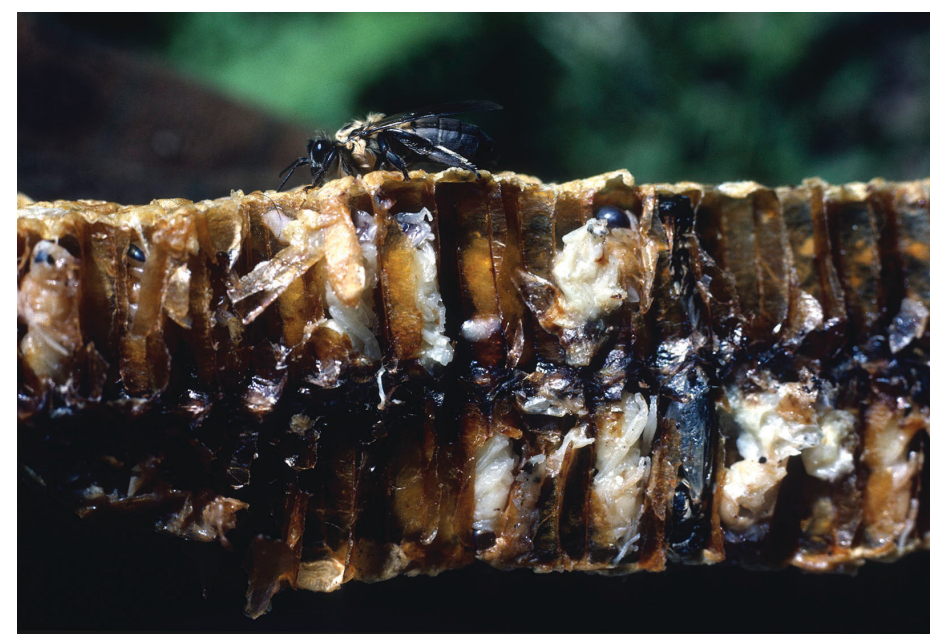

Figure 5. The remains of an Apis laboriosa nest, destroyed during a honey hunt in Nepal.

Credits: "The Honey Hunters" by @ Eric Valli http://www.ericvalli.org/ honey-hunters-eric-valli-photos/, used with permission

\section{Biology}

Apis laboriosa are similar to other honey bees in that they are considered eusocial or truly social insects. They meet these requirements for several reasons, one being that there is a reproductive division of labor among two female castes, the queens and workers. The queen is the only female within the colony to lay eggs and the workers collectively care for the brood, even though they do not normally produce any themselves (Mortensen et al. 2015). Apis laboriosa queens can produce many generations of workers per year, with some overlap; thus, meeting all the requirements of classifying organisms as eusocial.

In a single Apis laboriosa colony there may be thousands of workers (non-reproductive females) that complete all the tasks that keep the colony functioning (Corlett 2011). They tend to the brood and the queen as she cannot feed herself. They produce wax to build and maintain the single comb nest (Figure 6). They forage for pollen and nectar that is brought back to the colony to prepare food products. With their large body size and wing span, they are known to forage up to $2.5 \mathrm{mi}(4,100 \mathrm{~m})$ (Thapa et al. 2018).

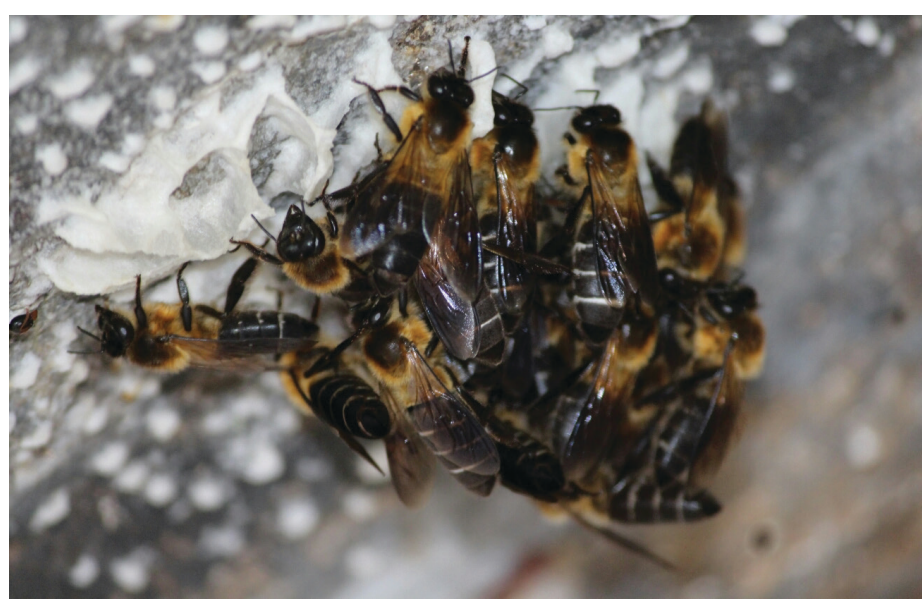

Figure 6. Apis laboriosa workers (non-reproductive females) building a nest in Omba, Trashiyangtse Dzongkhag, Trashiyangtse District, Bhutan with an elevation of approximately $7,129 \mathrm{ft}(2,173 \mathrm{~m})$ above sea level.

Credits: tandinwangchuk1 https://www.inaturalist.org/ observations/10593425, (CC BY 4.0) https://creativecommons.org/ licenses/by/4.0/

The nest is designed as a large, single comb that is exposed on all sides, which is similar to Apis dorsata. Apis laboriosa colonies aggregate close together with their nests typically found in steep, rocky cliffs attached to the underside of an overhanging ledge for protection from the elements (Figure 7). Nests can easily reach $4.9 \mathrm{ft}(1.5 \mathrm{~m})$ long by $3.3 \mathrm{ft}(1 \mathrm{~m})$ wide (or larger) and are often located on a southwest or southeast facing sheer rock cliff at elevations from 3,937 - 12,123 ft (1,200 - $4000 \mathrm{~m}$ ) above sea level (Ahmad et al. 2003; Otis 1996; Trung et al. 1996; Allen 1995; Valli and Summers 1988; Roubik et al. 1985). In areas of distribution that overlap with Apis dorsata, the nesting elevation separates the two species as Apis dorsata typically nests at altitudes below 4,921 ft (1,500 m) (Allen 1995; Roubik et al. 1985).

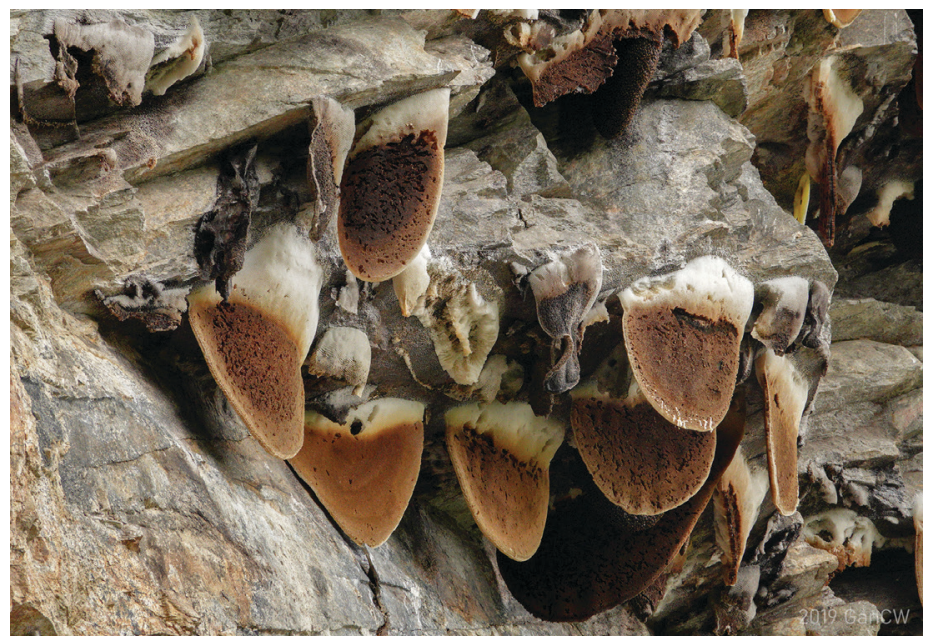

Figure 7. A nesting site of Apis laboriosa in Zhemgang, Bhutan with an elevation of approximately 2,121 m above sea level. Credits: CheongWeei Gan https://www.inaturalist.org/ photos/44194596, (CC BY-NC 4.0) https://creativecommons.org/ licenses/by-nc/4.0/ 
Apis laboriosa seasonally migrates to different altitudes to avoid harsh environmental conditions. From May to October the bees migrate upward to previous nesting sites $8,202-11,483 \mathrm{ft}(2,500-3,500 \mathrm{~m})$ above sea level. As temperatures begin to cool the bees migrate down to previous nesting sites $3937 \mathrm{ft}(1,200 \mathrm{~m})$ above sea level. Before the coldest temperatures of late November to early January the bees migrate once again to the forest ground and shelter at the base of trees or under rocks. The bees will not have a nest, but cluster together to keep warm until early spring. In late January the bees will return to their mid-level nesting site where they will stay until summer (Thapa et al. 2018; Woyke et al. 2012a; Hepburn 2011).

Woyke et al. (2012b) studied the specific placement of each Apis laboriosa nest on a cliff and noticed that Apis laboriosa were more likely to nest on lighter colored rocks, as it is often an indication of being better protected from the elements (Figure 8). Additionally, Apis laboriosa nesting sites are likely to only be 65-656 ft (20-200 m) away from major sources of water (Figure 9) (Ahmad et al. 2003).

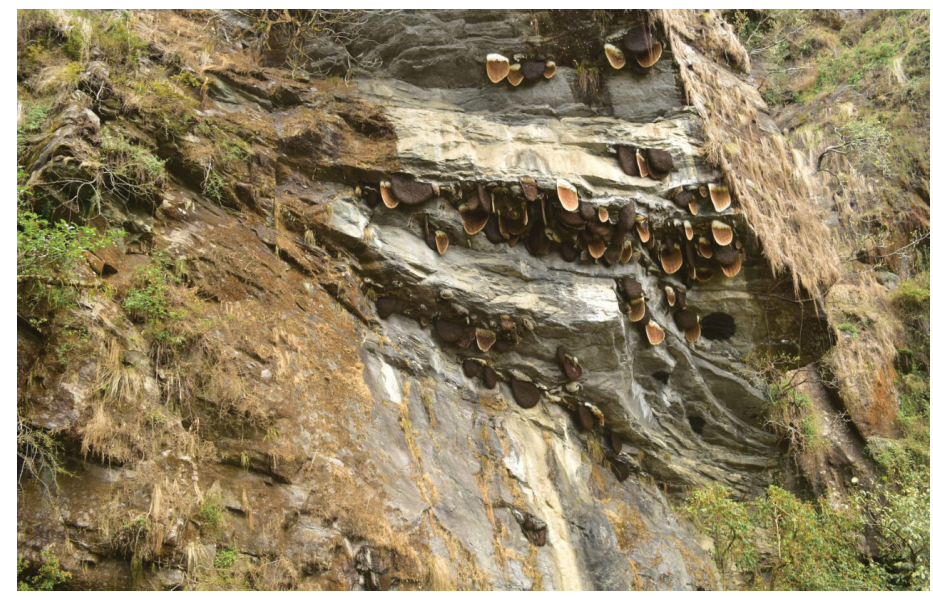

Figure 8. A Himalayan cliff displaying different colors of rock from which Apis laboriosa chooses to build its nest. Location: Nepal. Credits: ๑ Ganesh Sharma, used with permission

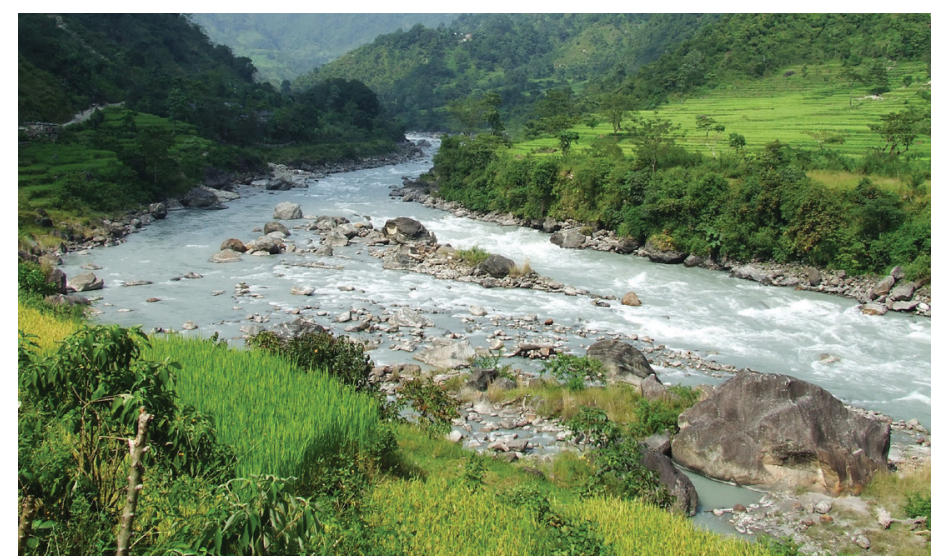

Figure 9. Mountain valley in the Himalayan region.

Credits: unknown / public domain https://pxhere.com/en/

photo/687060, (CCO 1.0) https://creativecommons.org/publicdomain/ zero/1.0/
An interesting defense behavior used by members of the subgenus Megapis is called shimmering (Figure 10). This defense method involves bees raising their abdomens in sequential order, sending waves across the surface of the nest. Watching honey bees move this way is thought to intimidate and possibly confuse the predator, making it difficult to single out one bee to attack (Woyke et al. 2008).

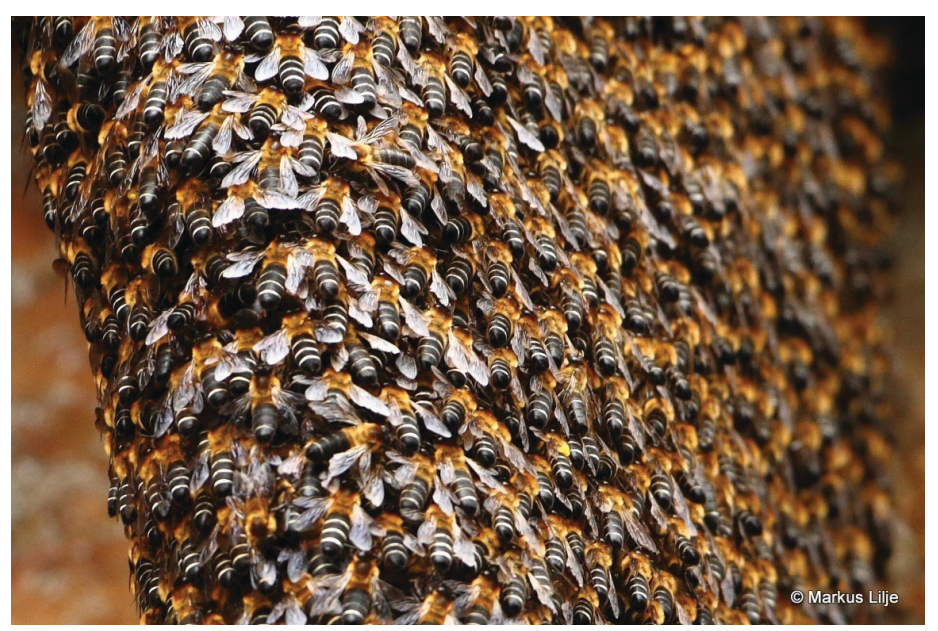

Figure 10. Overlapping layers of Apis laboriosa workers (nonreproductive females) forming a curtain on a large, single honeycomb, that hangs exposed. Located in Themnangbi, Mongar Dzongkhag, Mongar District, Bhutan at an elevation of approximately $7,382 \mathrm{ft}$ $(2,250 \mathrm{~m})$ above sea level.

Credits: Markus Lilje https://www.inaturalist.org/ observations/6899529, (CC BY-NC-ND 4.0) https://creativecommons. org/licenses/by-nc-nd/4.0/

\section{Economic Impact}

Apis laboriosa in Nepal produce an average yield of 55-132 lbs $(25-60 \mathrm{~kg})$ of honey per colony, per year (Thapa et al. 2018; Aryal et al. 2015), producing different types of honey depending on the season. Honey produced by Apis laboriosa has a high moisture content and ferments fast (Thapa et al. 2018). As Apis laboriosa nest at high elevations, collecting honey can be challenging. A tribal tradition called honey hunting has taken place for thousands of years in Nepal and the HKH region. Men of the tribe build ladders of rope and wooden rungs that are secured to land above the nests (Figure 11). From below, a fire is set to smoke the honey bees away from their nests (Figure 12). A man will climb the ladder to cut the nests down, collecting them in a basket. Figure 13 is a closer image that indicates the nest size by the ladder.

Honey hunters bring in more than $50 \%$ of the annual honey yield in the region (Ahmad et al. 2003). This destructive hunting practice has directly contributed to the rapid decline of the Apis laboriosa population in recent decades (Thapa et al. 2018; Joshi et al. 2004). Other possible contributors to the alarming decline may include land loss 
from deforestation and landslides, (Thapa et al. 2018; Aryal et al. 2015; Joshi et al. 2004; Ahmad et al. 2003) or parasites and diseases (Chantawannakul et al. 2016; Anderson \& Morgan 2007; Allen et al. 1990).

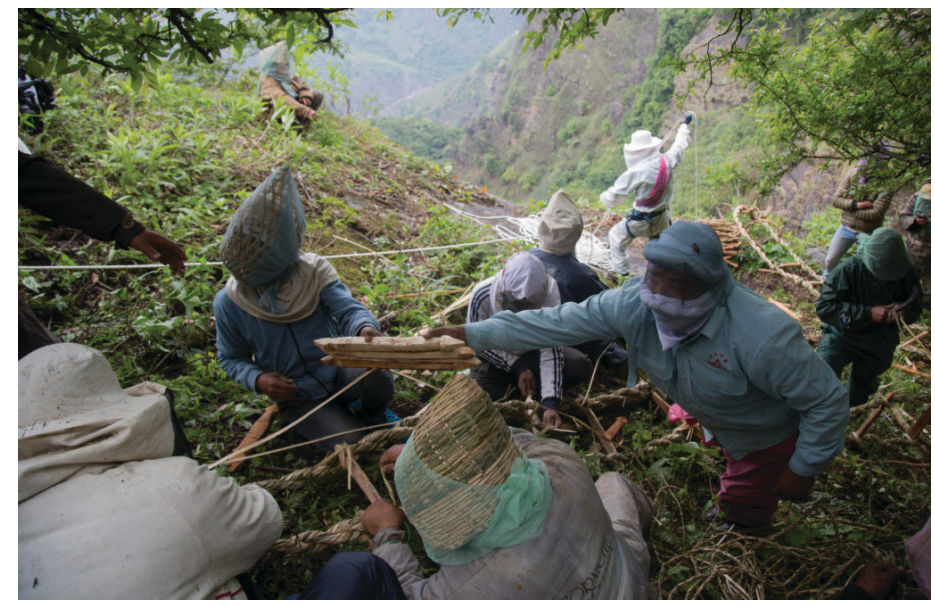

Figure 11. Nepalese men of the Gurung tribe fashion ladders out of braided bamboo ropes and wooden rungs before each hunt. Credits: @ David Caprara, used with permission

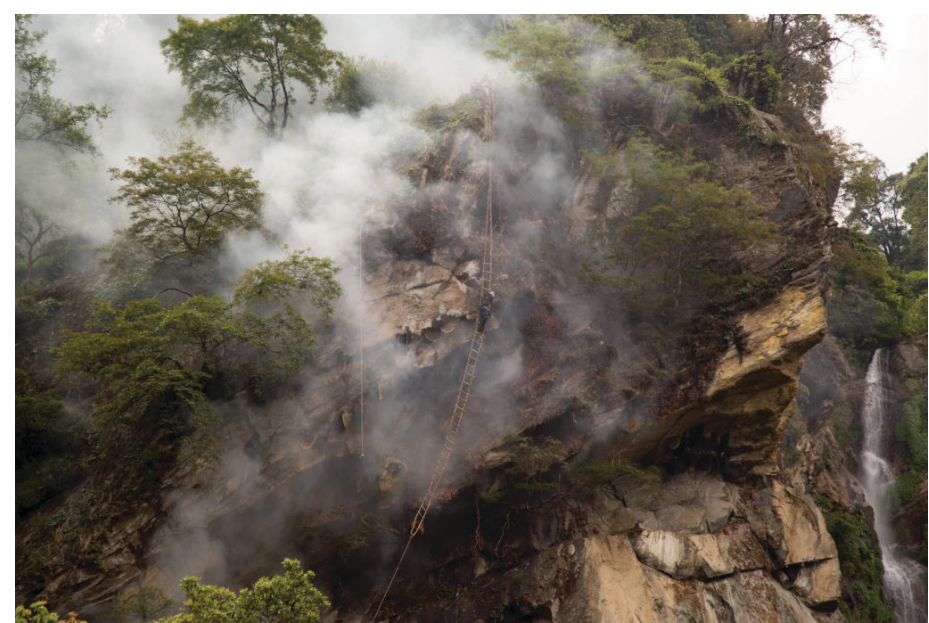

Figure 12. Nepalese men of the Gurung tribe have lit a fire at the bottom of the cliff. The smoke rises upwards to the nest to act as a deterrent against the Apis laboriosa nest defenders.

Credits: $\odot$ David Caprara, used with permission

The most valuable honey is known as red, psychedelic, or mad honey and is produced in the spring when plants of the Ericaceae family are in bloom. The nectar and pollen are collected at high altitude between $8202-12,795 \mathrm{ft}$ (2500-3900 m) above sea level, from several Rhododendron (Figure 14), Pieris, Agarista and Kalmia genera that contain grayanotoxins which appear to be harmless to the bees that collect and produce the honey (Roubik et al. 1985). While rarely fatal to humans, some have appeared dead or felt close to death in the days following consumption of mad honey.



Figure 13. For Apis laboriosa nest size reference, look at the ladder next to the men in Figure 11

Credits: @ David Caprara http://www.davidcaprara.com/the-honeyhunters-of-nepal/, used with permission

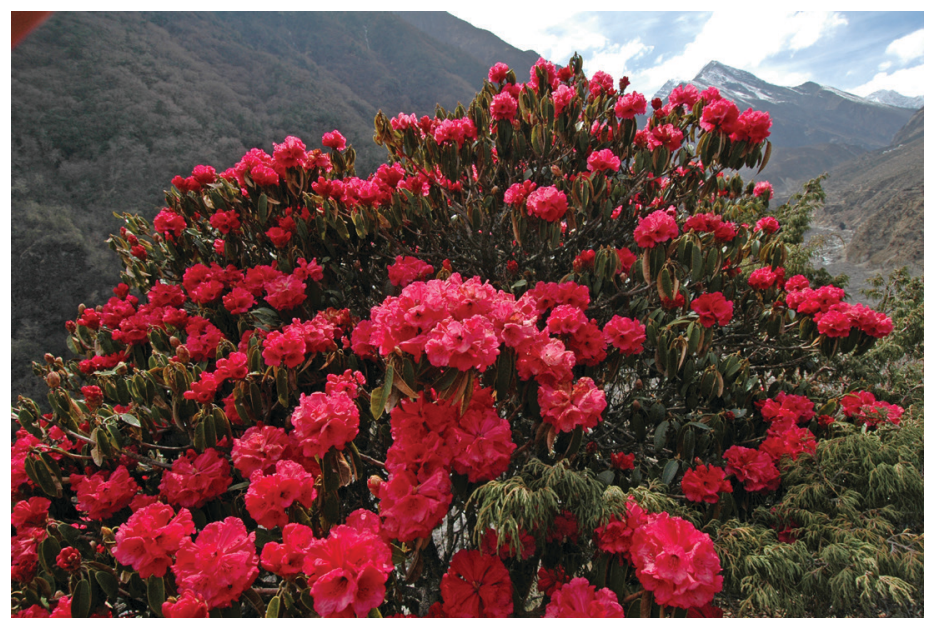

Figure 14. Rhododendron Forest in the Sagarmatha National Park, Himalaya, Nepal. Apis laboriosa workers visit rhododendron flowers during the spring to create what is known as mad honey. Credits: Peter Prokosch https://www.grida.no/resources/1598, (CC BYNC-SA 2.0) https://creativecommons.org/licenses/by-nc-sa/2.0/

Some try mad honey hoping to experience the claims of euphoria or relaxation. Others consume it for it is believed therapeutic properties which have been rumored to treat or even cure conditions such as hypertension, diabetes, and sexual dysfunction. Depending on the amount of mad honey consumed, the reactions to grayanotoxin poisoning could result in acute onset of: nausea, vomiting, diarrhea, prolific sweating, double or blurred vision, extreme physical weakness (or emotional exhaustion), along with low blood pressure, slow heart rate, unresponsiveness to stimuli, symptoms that resemble cardiac events, and in severe cases loss of consciousness, seizures, or even death. The poisoning and list of symptoms are collectively known as mad honey disease (Broscaru et al. 2018). 


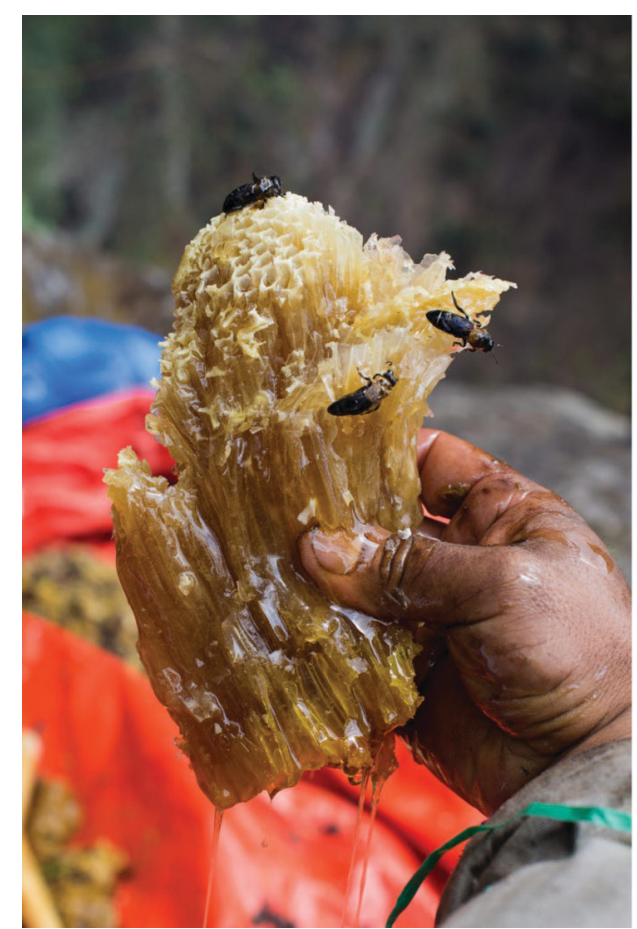

Figure 15. Harvested Apis laboriosa comb with honey squeezed from the comb.

Credits: @ David Caprara http://www.davidcaprara.com/the-honeyhunters-of-nepal/, used with permission

\section{Management}

Nepalese honey hunting practices require modification to promote honey bee sustainability. Without intervention, the Gurung tradition passed down for thousands of years will likely die as well. Programs by the International Centre for Integrated Mountain Development promote beekeeping to generate income through a sustainable practice so they can continue their traditions of collecting honey and beeswax (Ahmad et al. 2007).

As Apis laboriosa has a limited distribution, there is little evidence to suggest that this bee might become an invasive species in the United States. Nevertheless, its presence, along with all other honey bee species, is monitored by the Florida Department of Agriculture and Consumer Services Apiary Inspection service to ensure early detection were it ever to arrive in Florida, USA.

\section{Selected References}

Ahmad F, Joshi SR, Gurung MB. 2003. Indigenous honeybees of the Himalayas. The Himalayancliff bee Apis laboriosa Smith and the honey hunters of Kaski (Volume 1). International Center for Integrated Mountain Development. Kathmandu, Nepal. https://lib.icimod.org/ record/21832
Ahmad F, Joshi SR, Gurung MB. 2007. Beekeeping and Rural Development. International Center for Integrated Mountain Development. Kathmandu, Nepal. https://lib.icimod.org/api/files/2b0d4d56-3052-430b-bce8-96fb0fabd6ff/ attachment_301.pdf

Allen MF. 1995. "Bees and beekeeping in Nepal." Bee World 76(4):185-194. doi:10.1080/0005772X.1995.11099269

Allen MF, Ball BV, Underwood BA. 1990. "An isolate of Melissococcus pluton from Apis laboriosa." Journal of Invertebrate Pathology 55(3):439-40. doi:10.1016/0022-2011(90)90090-S

Anderson DL, Morgan MJ. 2007. "Genetic and morphological variation of bee-parasitic Tropilaelaps mites (Acari: Laelapidae): new and re-defined species." Experimental and Applied Acarology 43:1-24. doi:10.1007/s10493-007-9103-0

Aryal S, Thapa R, Jung, C. 2015. "An overview of beekeeping economy and its constraints in Nepal." Journal of Apiculture 30(3):135-142.

Broscaru L, Dobre C, Rösick F, Halilovic A, Gulba D. 2018. "Mad honey disease." European Journal of Case Reports in Internal Medicine 5(1):000742. doi:10.12890/2017_000742

Cao LF, Zheng HQ, Hu CY, He SY, Kuang HO, Hu FL. 2012. "Phylogeography of Apis dorsata (Hymenoptera: Apidae) from China and neighboring Asian areas." Annals of the Entomological Society of America 105(2):298-304.

Chantawannakul P, de Guzman LI, Li J, Williams G. 2016. "Parasites, pathogens, and pests of honeybees in Asia." Apidologie 47(3):301-324 doi:10.1007/s13592-015-0407-5

Corlett RT. 2011. Honeybees in Natural Ecosystems. In: Hepburn H, Radloff S. (eds) Honeybees of Asia. Springer, Berlin, Heidelberg. doi:10.1007/978-3-642-16422-4_10

Engel MS. 1999. "The taxonomy of recent and fossil honey bees (Hymenoptera: Apidae; Apis)." Journal of Hymenoptera Research 8(2):165-196. https://kuscholarworks.ku.edu/ bitstream/handle/1808/16476/Engel_JoHR_8(2)165. pdf?sequence $=1$

Hepburn HR. 2011. Absconding, Migration and Swarming. In: Hepburn H, Radloff S. (eds) Honeybees of Asia. Springer, Berlin, Heidelberg. doi:10.1007/978-3-642-16422-4_7 
Joshi SR, Ahmad F, Gurung MB. 2004. "Status of Apis laboriosa populations in Kaski district, western Nepal." Journal of Apicultural Research 43(4):176-80. doi:10.1080/00 218839.2004.11101133

Kitnya N, Prabhudev MV, Bhatta CP, Pham TH, Nidup T, Megu K, Chakravorty J, Brockmann A, Otis GW. 2020. "Geographical distribution of the giant honey bee Apis laboriosa Smith, 1871 (Hymenoptera, Apidae)." ZooKeys 951:67.

Koeniger G, Koeniger N, Phiancharoen M. 2011. Comparative Reproductive Biology of Honeybees. In: Hepburn H, Radloff S. (eds) Honeybees of Asia. Springer, Berlin, Heidelberg. doi:10.1007/978-3-642-16422-4_8

Koeniger N, Koeniger G, Smith D. 2011. Phylogeny of the Genus Apis. In: Hepburn H., Radloff S. (eds) Honeybees of Asia. Springer, Berlin, Heidelberg. doi:10.1007/978-3-642-16422-4_2

Mortensen AN, Smith B, Ellis JD. 2015. The Social Organization of Honey Bees. ENY-166. Gainesville, FL: University of Florida Institute of Food and Agricultural Sciences. https://edis.ifas.ufl.edu/publication/IN1102 (2 July 2019)

Otis GW. 1996. "Distributions of recently recognized species of honeybees (Hymenoptera: Apidae: Apis) in Asia." Journal of the Kansas Entomological Society 69:311-333.

Radloff SE, Hepburn HR, Engel MS. 2011. The Asian Species of Apis. In: Hepburn H, Radloff S. (eds) Honeybees of Asia. Springer, Berlin, Heidelberg. doi:10.1007/978-3-642-16422-4_1

Roubik DW, Sakagami S, Kudo I. 1985. "Note on Distribution and Nesting of the Himalayan Honey Bee Apis laboriosa Smith (Hymenoptera: Apidae)." Journal of the Kansas Entomological Society 58(4):746-749.

Sakagami SF, Matsumura T, Ito K. 1980. “Apis laboriosa in Himalaya, the little known world largest honeybee (Hymenoptera, Apidae)." Insecta Matsumurana 19:47-78.

Smith F. 1871. "A Catalogue of the Aculeate Hymenoptera and Ichneumonidae of India and the Eastern Archipelago." Journal of the Linnean Society of London, Zoology 11(53), 285-348. doi:10.1111/j.1096-3642.1871.tb02225.x
Smith F. 1871. A Catalogue of the "Aculeate Hymenoptera and Ichneumonidae of India and the Eastern Archipelago. (continued.)." Journal of the Linnean Society of London, Zoology 11(54), 349-415. doi:10.1111/j.1096-3642.1871. tb01662.x

Tan, NQ. 2007. "Biology of Apis dorsata in Vietnam." Apidologie 38: 221-229. doi: 10.1051/apido:2007002

Thapa R, Aryal S, Jung C. 2018. Beekeeping and honey hunting in Nepal: Current status and future perspectives. Asian Beekeeping in the 21 st Century. Springer, Singapore. 111-127. doi:10.1007/978-981-10-8222-1

Trung LQ, Dung PX, Ngan TX. 1996. "A scientific note on first report of Apis laboriosa F Smith, 1871 in Vietnam." Apidologie 27:487-488.

Valli E, Summers D. 1988. Honey hunters of Nepal. Thames and Hudson.

Woyke J, Wilde J, Wilde M. 2012a. "Swarming and migration of Apis dorsata and Apis laboriosa honey bees in India, Nepal and Bhutan." Journal of Apicultural Science 56(1):81-91.

Woyke J, Wilde J, Wilde M. 2012b. "Which mountain cliffs do Apis laboriosa honey bees select as nesting sites and why?" Journal of Apicultural Research 51(2):193-203.

Woyke J, Wilde J, Wilde M, Sivaram V, Cervancia C, Nagaraja N, Reddy M. 2008. "Comparison of defense body movements of Apis laboriosa, Apis dorsata dorsata and Apis dorsata breviligula honey bees." Journal of Insect Behavior 21(6):481-94. 